\title{
Inhibition of Prostacyclin by
}

\section{Treatment of Endothelium with Aspirin}

\author{
CORRELATION WITH PLATELET ADHERENCE
}

\author{
Robert L. Czervionke, J. Bryan Smith, Glenna L. Fry, John C. Hoak, and \\ DonNa L. HAYCRAFT, Specialized Center of Research in Atherosclerosis \\ and the Cardiovascular Center, University of Iowa College of Medicine, \\ Iowa City, Iowa 52242; and the Cardeza Foundation, Thomas Jefferson \\ University, Philadelphia, Pennsylvania 19107
}

A B S T R A C T Aspirin treatment of cultured endothelial cells from the umbilical vein increased the adherence of ${ }^{51} \mathrm{Cr}$-platelets when thrombin was present. If the cyclooxygenase activity of endothelium was inhibited by aspirin, as it is in the platelet, reduction of endogenous prostacyclin $\left(\mathrm{PGI}_{2}\right)$ production could have been responsible. By correlating thrombin-induced adherence of platelets to endothelial monolayers with $\mathrm{PGI}_{2}$ release (as measured by radioimmunoassay for 6-keto-prostaglandin $\mathrm{FI}_{1 \alpha}$ [6-keto-PGF $\left.{ }_{1 \alpha}\right]$ ), we have demonstrated an inverse relationship between platelet adherence and $\mathrm{PGI}_{2}$ levels. Untreated endothelial monolayers exposed to thrombin and platelets resulted in $4 \%$ platelet adherence and $107 \mathrm{nM}$ 6-ketoPGF $_{1 \alpha}$. With $0.1 \mathrm{mM}$ aspirin treatment, which is known to block platelet cyclooxygenase, adherence was 5\% and 6-keto-PGF ${ }_{1 \alpha}$ decreased to $45 \mathrm{nM}$. Increasing the aspirin concentration to $1 \mathrm{mM}$ resulted in $44 \%$ adherence and $<3 \mathrm{nM} 6$-keto-PGF ${ }_{1 \alpha}$. When $25 \mathrm{nM}$ exogenous $\mathrm{PGI}_{2}$ was added to $1 \mathrm{mM}$ aspirin-treated endothelium, adherence returned to $5 \%$. The increase in thrombin-induced platelet adherence to $1 \mathrm{mM}$ aspirintreated monolayers was reversed $2 \mathrm{~h}$ after removal of the aspirin solution. 6-Keto- $\mathrm{PGF}_{1 \alpha}$ returned to $37 \%$ of the untreated monolayer value. Recovery from the aspirin effect did not occur when cycloheximide, an inhibitor of protein synthesis, was present during the 2-h period.

\section{INTRODUCTION}

We have reported recently that minimal platelet adherence to endothelium occurred if thrombin, plate-

This work was presented in part at the 5lst Annual Meeting of the American Heart Association, Dallas, Texas, 15 November 1978 . lets, and endothelium were incubated simultaneously (1). This thrombin-induced platelet adherence could be enhanced by preincubation of the endothelium with a high dose of aspirin. The increased adherence was seen even when aspirin-treated platelets were used. The aspirin effect on the endothelium was temporary.

The present study was undertaken to determine whether prostacyclin $\left(\mathrm{PGI}_{2}\right)^{1}$, the inhibitor of platelet aggregation found predominantly in the vascular intima (2), was involved in the aspirin modification of thrombin-induced platelet adherence to endothelium. This approach was suggested by our initial finding that cultured endothelial cells, but not our fibroblast or smooth muscle cells, yielded 6-keto-prostaglandin $F_{1 \alpha}\left(6\right.$-keto-PGF $\left.F_{1 \alpha}\right)$, the stable end product of $\mathrm{PGI}_{2}$, in response to thrombin (1). The thrombininduced release of $\mathrm{PGI}_{2}$ from confluent monolayers of cultured human umbilical vein endothelium has been detailed in subsequent studies $(3,4)$.

\section{METHODS}

The preparation of confluent monolayers in $35 \times 10 \mathrm{~mm}$ culture dishes of primary human umbilical vein endothelium (7-8 $\times 10^{5}$ cells; $0.2-0.3 \mathrm{mg}$ protein) and passed umbilical artery fibroblasts has been described elsewhere (1). Emptydish controls were culture dishes that were handled exactly as dishes that contained cells. Incubation medium (IM): $8.6 \mathrm{~g}$ /liter bovine serum albumin, $140.3 \mathrm{mM} \mathrm{NaCl}, 5.8 \mathrm{mM}$ $\mathrm{KCl}, 2.7 \mathrm{mM} \mathrm{CaCl}$, and $16.3 \mathrm{mM}$ Tris, $\mathrm{pH} \mathrm{7.4}$. Monolayer washing buffer: Hank's balanced salt solution without $\mathrm{NaHCO}_{3}$, and $15 \mathrm{mM}$ Hepes, pH 7.4. The source of reagents and the preparation of solutions not specifically detailed below have been reported $(1,4)$.

Adherence or $\mathrm{PGI}_{2}$ procedure. The adherence of ${ }^{51} \mathrm{Cr}$ -

${ }^{1}$ Abbreviations used in this paper: ASA, acetylsalicylic acid or aspirin; IM, incubation medium; 6-keto-PGF ${ }_{1 \alpha}, 6$-ketoprostaglandin $\mathrm{F}_{1 \alpha} ; \mathrm{PGI}_{2}$, prostaglandin $\mathrm{I}_{2}$ or prostacyclin. 
platelets to endothelium previously treated with acetylsalicylic acid or aspirin (ASA) has been described (1). Studies to determine $\mathrm{PGI}_{2}$ release were identical to the adherence studies through the monolayer incubation procedure with thrombin and platelets, except that unlabeled washed platelets were employed. Briefly, $1 \mathrm{ml} \mathrm{ASA}$ in $\mathrm{IM}$ or $1 \mathrm{ml} \mathrm{IM}$ (control) was incubated with the monolayer for $30 \mathrm{~min}$ at $37^{\circ} \mathrm{C}$ with rocking. The preincubation solution was removed and the monolayer was washed twice. $1 \mathrm{ml} 0.5 \mathrm{U} / \mathrm{ml}$ bovine thrombin in IM or $1 \mathrm{ml}$ IM was added, followed immediately by $0.5 \mathrm{ml}$ Tyrode's solution with human ${ }^{51} \mathrm{Cr}$-platelets (for adherence) or unlabeled platelets (for $\mathrm{PGI}_{2}$ studies). The dish was rocked $30 \mathrm{~min}$ at $37^{\circ} \mathrm{C}$.

For the adherence determination, the suspension that contained unattached platelets was removed, and the monolayer was washed twice. The monolayer and attached ${ }^{51} \mathrm{Cr}$ platelets were then solubilized and, after ${ }^{51} \mathrm{Cr}$-radioactivity was determined in all solutions, percent adherence was calculated by dividing monolayer counts per minute, multiplied by 100 , by the total counts per minute.

For the $\mathrm{PGI}_{2}$ determination, the suspension that contained unattached platelets was removed and centrifuged at $1,100 \mathrm{~g}$ for $15 \mathrm{~min}$. $\mathrm{PGI}_{2}$ (or 6-keto- $\mathrm{PGF}_{1 \alpha}$ ) in the supernate was determined by means of a radioimmunoassay for 6-ketoPGF $_{1 \alpha}(4)$.

Inhibition by exogenous $\mathrm{PGI}_{2}$ of platelet adherence to endothelium. A stock solution of $1 \mathrm{mM}$ synthetic $\mathrm{PGI}_{2}$ in $50 \mathrm{mM} \mathrm{Na} \mathrm{CO}_{3}$ was stored under $\mathrm{N}_{2}$ at $-20^{\circ} \mathrm{C}$. An aliquot of this $\mathrm{PGI}_{2}$ was thawed immediately before use, diluted, and then incubated with platelets and the monolayer or empty dish within $10 \mathrm{~min}$.

The monolayer or empty dish was pretreated with $1 \mathrm{mM}$ ASA and washed, as described above. Added immediately in rapid succession were $0.5 \mathrm{ml} \mathrm{IM}$ with or without three times the final concentration of $\mathrm{PGI}_{2}, 0.5 \mathrm{ml} \mathrm{IM}$ with $1 \mathrm{U} / \mathrm{ml}$ bovine thrombin (with mixing), and $0.5 \mathrm{ml}$ Tyrode's solution with ${ }^{51} \mathrm{Cr}$-platelets (with mixing). The monolayer or empty dish was then rocked $30 \mathrm{~min}$ at $37^{\circ} \mathrm{C}$. Adherence was determined as described above.

Determination of monolayer recovery from ASA. After the $1 \mathrm{mM} \mathrm{ASA}$ or control-buffer pretreatment and washing of the endothelium, the dish was immediately layered with $2 \mathrm{ml}$ culture medium, with or without $2.5 \mu \mathrm{g} / \mathrm{ml}$ cycloheximide (Sigma Chemical Co., St. Louis, Mo.). After a 2-h incubation without rocking as previously described (1), the medium was removed and the monolayer was washed twice. Thrombin and platelets were then rocked $30 \mathrm{~min}$ at $37^{\circ} \mathrm{C}$ with the endothelium. Platelet adherence or $\mathrm{PGI}_{2}$ release into the supernate was determined as described above.

Statistical method. Student's $t$ test was employed to determine statistical significance (5). Data represent a minimum of three experiments in duplicate. The handling of 6-keto$\mathrm{PGF}_{1 \alpha}$ data below the $3 \mathrm{nM}$ assay-detection limit has been described (4).

\section{RESULTS}

In Fig. 1, platelet adherence to untreated or ASApretreated venous endothelium was compared with the 6-keto-PGF ${ }_{1 \alpha}$ released into the incubation solution. In the absence of thrombin, $\cong 2 \%$ adherence was observed for untreated $(1.7 \pm 0.4 \%)$ and ASA-treated monolayers $(2.4 \pm 0.4 \%, 0.1 \mathrm{mM}$ ASA; $1.4 \pm 0.1 \%, 1 \mathrm{mM}$ ASA). 6-Keto- $\mathrm{PGF}_{1 \alpha}$ decreased from the $18.8 \pm 2.7$ $\mathrm{nM}$ base-line level observed with untreated endothelium, to $<3.0 \pm 0.5 \mathrm{nM}$ with $0.1 \mathrm{mM}$ ASA-treated

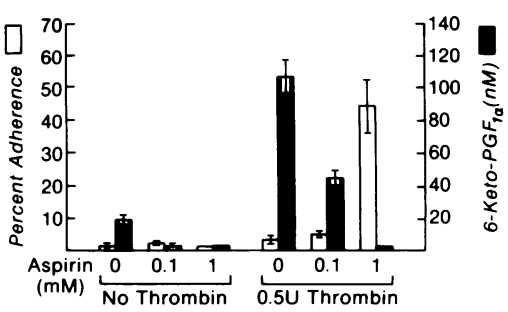

FIGURE 1 Platelet adherence to untreated and ASA-treated endothelium compared with 6-keto- $\mathrm{PGF}_{1 \alpha}$ release. ASA or buffer control was incubated with the monolayer for $30 \mathrm{~min}$ at $37^{\circ} \mathrm{C}$ with rocking. The preincubation solution was removed and the dish was washed twice. Thrombin or buffer control was added, followed immediately by ${ }^{51} \mathrm{Cr}$-platelets (for adherence) or unlabeled platelets (for $\mathrm{PGI}_{2}$ determinations). The monolayer was rocked $30 \mathrm{~min}$ at $37^{\circ} \mathrm{C}$. Percent adherence was calculated by dividing counts per minute of cells attached to the monolayer, mutiplied by 100 , by total counts per minute added to the dish. 6-Keto-PGF ${ }_{1 \alpha}$ released into the supernate was determined by radioimmunoassay.

endothelium, and then below the $3.0 \pm 0 \mathrm{nM}$ assaydetection level with the $1 \mathrm{mM}$ ASA-treated cells. It should be noted that the $18.8 \pm 2.7 \mathrm{nM} 6$-keto-PGF $1 \alpha$ value is obtained not from resting cells, but from untreated monolayers subjected to rocking. Previously, we have calculated (4) that this level is quantitatively similar to the $\mathrm{PGI}_{2}$ reported in stirred suspensions of human umbilical vein endothelium (6).

In the presence of $0.5 \mathrm{U}$ thrombin (Fig. 1), $3.8 \pm 0.9 \%$ platelet adherence and 106.7 $\pm 10.2 \mathrm{nM}$ 6-keto-PGF ${ }_{1 \alpha}$ were observed with the untreated monolayer. With $0.1 \mathrm{mM}$ ASA-treated monolayers, adherence was 5.4 $\pm 0.7 \%$, whereas 6 -keto- PGF $_{1 \alpha}$ decreased to $44.9 \pm 4.5$ $\mathrm{nM}$. With $1 \mathrm{mM}$ ASA-treated monolayers, adherence increased significantly to $44.2 \pm 8.2 \%$ and 6 -keto-PGF ${ }_{1 \alpha}$ was $<3.0 \pm 0 \mathrm{nM}$.

The ASA-induced increase in platelet adherence to endothelium was offset by the addition of exogenous $\mathrm{PGI}_{2}$, as is shown in Fig. 2. For this study, the monolayer was treated with $1 \mathrm{mM}$ ASA to completely inhibit $\mathrm{PGI}_{2}$ release. Immediately before the addition of thrombin and platelets, synthetic $\mathrm{PGI}_{2}$ was added to the dish. Platelet adherence to endothelium declined from the $49.2 \pm 2.5 \%$ observed in the absence of $\mathrm{PGI}_{2}$ to $18.0 \pm 3.6,12.3 \pm 1.8,6.2 \pm 0.7$, and $5.3 \pm 0.6 \%$ when a final concentration of $5,10,15$, and $25 \mathrm{nM} \mathrm{PGI}_{2}$ was used. This response to $\mathrm{PGI}_{2}$ was significantly greater than that observed with the empty dish or fibroblast controls (Fig. 2). Adherence to the ASA-treated empty dish decreased minimally from $81.0 \pm 1.2 \%$ in the absence of $\mathrm{PGI}_{2}$ to $74.4 \pm 1.7 \%$ with $25 \mathrm{nM} \mathrm{PGI}_{2}$. Adherence to the ASA-treated fibroblast monolayer declined from $74.9 \pm 1.1 \%$ to $65.9 \pm 1.7 \%$ in the same $\mathrm{PGI}_{2}$ range.

The duration of the ASA effect on endothelium, as reflected by thrombin-induced adherence and 6-keto- 


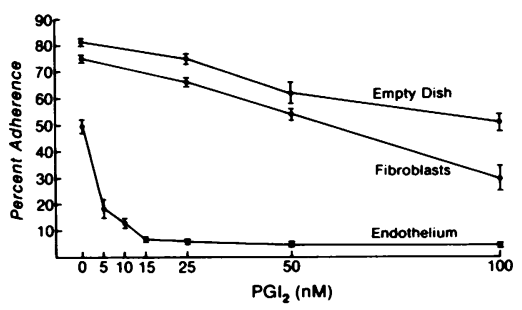

FIgURE 2 Inhibition by exogenous $\mathrm{PGI}_{2}$ of $0.5 \mathrm{U}$ thrombininduced platelet adherence to ASA-treated endothelium, fibroblasts, and empty dishes. $1 \mathrm{mM}$ ASA was incubated with the monolayer or empty dish for $30 \mathrm{~min}$ at $37^{\circ} \mathrm{C}$ with rocking. The ASA solution was removed and the cell layer or dish was washed twice. Added immediately were synthetic $\mathrm{PGI}_{2}$, thrombin, and ${ }^{51} \mathrm{Cr}$-platelets. The monolayer or empty dish was rocked $30 \mathrm{~min}$ at $37^{\circ} \mathrm{C}$. Percent adherence was calculated by dividing counts per minute of cells attached to the monolayer, multiplied by 100 , by total counts per minute added to the dish.

$\mathrm{PGF}_{1 \alpha}$ release, is shown in Fig. 3. In the absence of ASA, $0.5 \mathrm{U}$ thrombin-induced platelet adherence was $10.9 \pm 5.0 \%$ and 6 -keto- PGF $_{1 \alpha}$ release was $124.0 \pm 11.7$ $\mathrm{nM}$ for the monolayer incubated immediately with thrombin and platelets ( $0-h$ recovery). These values are not significantly different from those (not shown in Fig. 3) observed with endothelium not treated with ASA, which had been placed back into the growth medium with or without cycloheximide for $2 \mathrm{~h}$.

With the $1 \mathrm{mM}$ ASA-treated endothelium (Fig. 3), $46.2 \pm 5.8 \%$ platelet adherence and 6-keto- $\mathrm{PGF}_{1 \alpha}$ release below detectable levels $(<3.0 \pm 0 \mathrm{nM})$ were observed when the monolayer was immediately incubated with $0.5 \mathrm{U}$ thrombin and platelets. In contrast, $2 \mathrm{~h}$ after the ASA was removed from the endothelium, thrombin-induced adherence returned to $9.5 \pm 3.6 \%$, the base-line level observed with endothelium not

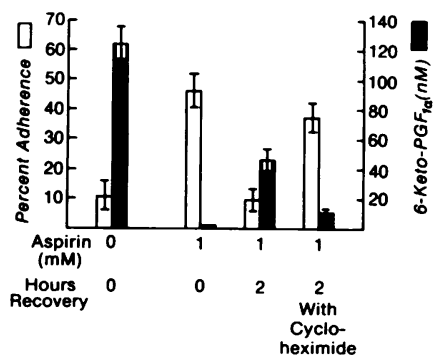

Figure 3 Duration of the ASA effect on endothelium as reflected by $0.5 \mathrm{U}$ thrombin-induced platelet adherence and 6-keto-PGF ${ }_{1 \alpha}$ release. ASA or buffer control was incubated with the monolayer for $30 \mathrm{~min}$ at $37^{\circ} \mathrm{C}$ with rocking. The preincubation solution was removed and the monolayer was washed twice. The designated monolayers were layered with $2 \mathrm{ml}$ culture medium with and without $2.5 \mu \mathrm{g} / \mathrm{ml}$ cycloheximide, incubated in a $5 \% \mathrm{CO}_{2}$ atmosphere at $37^{\circ} \mathrm{C}$ for $2 \mathrm{~h}$ (recovery period), and rewashed twice. All monolayers were then treated with thrombin and platelets as in Fig. 1. treated with ASA. This was associated with an increase of 6-keto- $\mathrm{PGF}_{1 \alpha}$ to $46.3 \pm 7.0 \mathrm{nM}$, a concentration shown in the study with exogenous $\mathrm{PGI}_{2}$ (Fig. 2) to inhibit platelet adherence to approximately the value observed here. When $2.5 \mu \mathrm{g} / \mathrm{ml}$ cycloheximide was present during the 2 -h recovery period from ASA (Fig. 3), the high level of platelet adherence was maintained at $37.1 \pm 4.9 \%$. This adherence was associated with $<11.0 \pm 2.2 \mathrm{nM}$ 6-keto-PGF ${ }_{1 \alpha}$.

\section{DISCUSSION}

An inverse relationship appears to exist between thrombin-stimulated $\mathrm{PGI}_{2}$ release from human umbilical vein endothelium, and thrombin-induced platelet adherence to the endothelial monolayer. In Fig. 1, low platelet adherence was associated with high 6-keto$\mathrm{PGF}_{1 \alpha}$ release from untreated endothelium, whereas high adherence and 6-keto-PGF ${ }_{1 \alpha}$ values below the assay-detection level were observed with $1 \mathrm{mM}$ ASAtreated endothelium. This inhibition by ASA of $\mathrm{PGI}_{2}$ activity in components of the blood vessel wall has also been observed by others (7-13).

Evidence that release of endogenous $\mathrm{PGI}_{2}$ is causative in inhibiting the thrombin-induced platelet adherence to endothelium was suggested by the data in Fig. 2. Adherence to endothelial monolayers that did not release endogenous $\mathrm{PGI}_{2}$ was reduced by adding synthetic $\mathrm{PGI}_{2}$ to the dishes before the incubation with thrombin and platelets. The study also indicates that the $\cong 100$-nM endogenous $\mathrm{PGI}_{2}$ capable of release by thrombin is more than sufficient to prevent adherence to the endothelium. However, factors other than $\mathrm{PGI}_{2}$ may also be involved in preventing thrombin-induced platelet adherence to endothelium. Similar amounts of exogenous $\mathrm{PGI}_{2}$ only partially decreased adherence to empty dishes or to fibroblasts (Fig. 2).

With $0.1 \mathrm{mM}$ ASA-treated endothelium (Fig. 1), thrombin-induced platelet adherence after a $30-\mathrm{min}$ incubation was not significantly increased over the level observed with the monolayer not treated with ASA. On the other hand, 6-keto-PGF ${ }_{1 \alpha}$ release was reduced to $44.9 \pm 4.5 \mathrm{nM}$, which is $42 \%$ of the nonASA-treated monolayer level. A 40-50-nM concentration of synthetic $\mathrm{PGI}_{2}$ has been shown to be more than sufficient to block thrombin-induced adherence to $1 \mathrm{mM}$ ASA-treated endothelium (Fig. 2). It should be noted that a plasma level of $\cong 0.1 \mathrm{mM}$ ASA is achieved 15 min after the ingestion of two ASA tablets (14). After a 20-min incubation, this same concentration of ASA effects a $95 \%$ decrease in platelet cyclooxygenase activity as determined by platelet malonaldehyde production $(1,15)$. Therefore, it appears that the cyclooxygenase that uses endogenous arachidonate in umbilical vein endothelium is more resistant to pharma- 
cological doses of ASA than is its platelet counterpart. Burch et al. (7) have reported that the fatty acid cyclooxygenase in microsomal fractions from human thoracic aorta or coronary artery is also less sensitive to ASA than is the cyclooxygenase in intact or disrupted platelets.

If placed in fresh culture medium after treatment with $1 \mathrm{mM}$ ASA, endothelium partially regains its capacity to inhibit adherence in $0.5 \mathrm{~h}(1)$, and completely recovers from the ASA effect in $2 \mathrm{~h}$ (Fig. 3). Thrombin-induced adherence to ASA-treated monolayers decreased from a high of $46.2 \pm 5.8 \%$ at $0 \mathrm{~h}$ to $9.5 \pm 3.6 \%$ at $2 \mathrm{~h}$. The latter value is not statistically different $(P<0.50)$ from the $10.9 \pm 5.0 \%$ adherence observed with non-ASA-treated monolayers at zero recovery time (Fig. 3). However, complete recovery of 6 -keto-PGF ${ }_{1 \alpha}$ release was not observed during the 2-h recovery period. 6-Keto- $\mathrm{PGF}_{1 \alpha}$ increased from below detectable levels, but only to $46.3 \pm 7.0 \mathrm{nM}$ which is approximately $37 \%$ of the $124.0 \pm 11.7-\mathrm{nM}$ level observed with endothelium without ASA at zero recovery time. This quick recovery from ASA is in agreement with Kelton et al. (12) who reported that the "thrombogenic" effect of high-dose ASA lasted about $2.5 \mathrm{~h}$ after its removal from rabbit tissue. In contrast, Gordon and Pearson (13) have reported that pig endothelium treated $24 \mathrm{~h}$ with $1 \mathrm{mM}$ ASA only slightly recovered its ability to inhibit platelet aggregation $24 \mathrm{~h}$ after removal of the ASA (13). However, pig endothelium treated with $0.1 \mathrm{mM}$ ASA substantially recovered during the same period.

Cycloheximide is a glutaramide antibiotic that inhibits protein synthesis in mammalian cells (16), and recently has been employed in studies with cultured umbilical vein endothelium (17). The ASA effect was maintained if this reagent was included in the culture medium during the 2 -h recovery period (Fig. 3), suggesting that protein synthesis may be required for the regeneration of enzymatic activity necessary for $\mathbf{P G I}_{2}$ production.

\section{ACKNOWLEDGMENTS}

We gratefully acknowledge the technical assistance of Ms. Judith Komlash and Ms. Connie Schroeder.

This work was supported in part by the National Heart, Lung, and Blood Institute through a Specialized Center of Research in Atherosclerosis (grant 14230), and by National Institutes of Health (grants HL-21239 and HL-14890).

\section{REFERENCES}

1. Czervionke, R. L., J. C. Hoak, and G. L. Fry. 1978. Effect of aspirin on thrombin-induced adherence of platelets to cultured cells from the blood vessel wall. J. Clin. Invest. 62: 847-856.

2. Moncada, S., A. G. Herman, E. A. Higgs, and J. R. Vane. 1977. Differential formation of prostacyclin (PGX or $\mathrm{PGI}_{2}$ ) by layers of the arterial wall. An explanation for the anti-thrombotic properties of vascular endothelium. Thromb. Res. 11: 323-344.

3. Weksler, B. B., C. W. Ley, and E. A. Jaffe. 1978. Stimulation of endothelial cell prostacyclin production by thrombin, trypsin, and the ionophore A 23187. J. Clin. Invest. 62: $923-930$.

4. Czervionke, R. L., J. B. Smith, J. C. Hoak, G. L. Fry, and D. L. Haycraft. 1979. Use of a radioimmunoassay to study thrombin-induced release of $\mathrm{PGI}_{2}$ from cultured endothelium. Thromb. Res. 14: 781-786.

5. Hill, A. B. 1961. Principles of Medical Statistics. The Lancet Ltd., London. 7th edition. 146-149.

6. Weksler, B. B., A. J. Marcus, and E. A. Jaffe. 1977. Synthesis of prostaglandin $I_{2}$ (prostacyclin) by cultured human and bovine endothelial cells. Proc. Natl. Acad. Sci. U. S. A. 74: 3922-3926.

7. Burch, J. W., N. L. Baenziger, N. Stanford, and P. W. Majerus. 1978. Sensitivity of fatty acid cyclooxygenase from human aorta to acetylation by aspirin. Proc. Natl. Acad. Sci. U. S. A. 75: 5181-5184.

8. Nord $\varnothing y$, A., B. Svensson, and J. C. Hoak. 1978. The inhibitory effect of human endothelial cell monolayers on platelet reactions and its inhibition by aspirin. Thromb. Res. 12: 597-608.

9. MacIntyre, D. E., J. D. Pearson, and J. L. Gordon. 1978. Localisation and stimulation of prostacyclin production in vascular cells. Nature (Lond.). 271: 549-551.

10. Marcus, A. J., B. B. Weksler, and E. A. Jaffe. 1978. Enzymatic conversion of prostaglandin endoperoxide $\mathrm{H}_{2}$ and arachidonic acid to prostacyclin by cultured human endothelial cells. J. Biol. Chem. 20: 7138-7141.

11. Villa, S., and G. de Gaetano. 1977. Prostacyclin-like activity in rat vascular tissues. Fast, long-lasting inhibition by treatment with lysine acetylsalicylate. Prostaglandins. 14: 1117-1124.

12. Kelton, J. G., J. Hirsh, C. J. Carter, and M. R. Buchanan. 1978. Thrombogenic effect of high-dose aspirin in rabbits. Relationship to inhibition of vessel wall synthesis of prostaglandin $\mathrm{I}_{2}$-like activity. J. Clin. Invest. 62: 892-895.

13. Gordon, J. L., and J. D. Pearson. 1978. Effects of sulphinpyrazone and aspirin on prostaglandin $I_{2}$ (prostacyclin) synthesis by endothelial cells. Br. J. Pharmacol. 64: 481-483.

14. Rowland, M., S. Riegelman, P. A. Harris, and S. D. Sholkoff. 1972. Absorption kinetics of aspirin in man following oral administration of an aqueous solution. J. Pharm. Sci. 61: 379-385.

15. Baenziger, N. L., M. J. Dillender, and P. W. Majerus. 1977. Cultured human skin fibroblasts and arterial cells produce a labile platelet-inhibitory prostaglandin. Biochem. Biophys. Res. Commun. 78: 294-301.

16. Bennett, L. L., Jr., V. L. Ward, and R. W. Brockman. 1965. Inhibition of protein synthesis in vitro by cycloheximide and related glutarimide antibiotics. Biochim. Biophys. Acta. 103: 478-485.

17. Maca, R. D., G. L. Fry, and A. D. Hakes. 1978. Effects of glucocorticoids on the interaction of lymphoblastoid cells with human endothelial cells in vitro. Cancer Res. 38: 2224-2228. 